\title{
Hubungan Antara Penguasaan Sintaksis Dan Penguasaan Nahwu Terhadap Kemampuan Menulis Teks Bahasa Arab \\ Pada Mahasiswa Jurusan Pendidikan Bahasa Arab Iain Pontianak
}

\author{
Midyan Surya Ishak \\ Institut Agama Islam Negeri Pontianak \\ midyansurya02@gmail.com
}

\begin{abstract}
The background of this study is lack of understanding student with Arabic thesis produced by students of Arabic Education department in IAIN Pontianak FTIK. Those problems arise because of the low understanding of the logical language rules between Arabic and Indonesian. This study was analyzed by calculating path analysis. Based on the results of the analysis, it can be concluded that: 1) there is no significant relationship between syntactic mastery and mastery of students majoring in PBA, path parameter coefficient between syntax and mastery of nahwu science of -0.148 with TStatistics of 0.868 and P-Values amounting to 0.387 , because $P>0.05,2$ ) there is a significant positive relationship between syntactic mastery and the ability to write Arabic student text because the path parameter coefficient value between the two variables is 0.524 with a T-statistic value of 3.626 and P-Values of 000 , because $P$ $<0.05,3)$ there was an insignificant relationship between the mastery of nahwu and the ability to write Arabic student text because it obtained the path parameter parameter coefficient between the two variables of 0.214 with a T-Statistical value of 1.2229 and $P$-Values of 0.221 , because $P>0.05$, 4) there is a significant relationship between mastery of sint simultaneous axis with mastery of student writing skills because the total effect of Syntax mastery together with the influence of mastery variables on writing ability is 0.493 with T statistic of 3.197 with P-Values level of 0.002 , because P-Values is $<0.05$, then $\mathrm{HO}$ is rejected.
\end{abstract}

Keywords: Mastery, syntax, nahwu, writing ability, Arabic text.

\begin{abstract}
Abstrak: Latar belakang penelitian ini adalah ketidakterpahaman skripsi Bahasa Arab yang dihasilkan oleh mahasiswa jurusan Pendidikan Bahasa Arab FTIK IAIN Pontianak. Problema tersebut muncul karena rendahnya pemahaman tentang tata aturan bahasa yang logis antara bahasa Arab dan bahasa Indonesia. Penelitian ini dianalisis dengan perhitungan analisis jalur. Berdasarkan hasil analisis, dapat disimpulkan bahwa :1) Tidak terdapat hubungan yang signifikan antara penguasaan sintaksis dan penguasaan nahwu mahasiswa jurusan PBA, nilai koefisien parameter jalur antara antara Sintaksis dengan Penguasaan Ilmu Nahwu sebesar -0,148 dengan nilai T-Statistik sebesar 0,868 dan P-Values sebesar 0,387, karena $\mathrm{P}>0.05,2$ ) terdapat hubungan positif yang signifikan antara penguasaan sintaksis dengan kemampuan menulis teks bahasa Arab mahasiswa karena diperoleh nilai koefisien parameter jalur antara kedua variabel tersebut sebesar 0,524 dengan nilai TStatistik sebesar 3,626 dan P-Values sebesar 0,00, karena $\mathrm{P}<0.05,3$ ) terdapat hubungan yang tidak signifikan antara penguasaan nahwu dan kemampuan menulis teks Arab mahasiswa karena diperoleh nilai koefisien parameter jalur antara antara kedua variabel tersebut sebesar 0,214 dengan nilai T-Statistik sebesar 1,229 dan PValues sebesar 0,221 , karena $\mathrm{P}>0.05,4$ ) terdapat hubungan signifikan antara penguasaan sintaksis secara simultan dengan penguasaan nahwu terhadap kemampuan menulis mahasiswa karena total pengaruh penguasaan Sintaksis secara bersama-sama dengan pengaruh variabel penguasaan nahwu terhadap kemampuan menulis sebesar 0,493 dengan T statistic sebesar 3,197 dengan tingkat P-Values sebesar 0,002, karena P-Values <0.05, maka H0 ditolak.
\end{abstract}

Kata kunci: Penguasaan, sintaksis, nahwu, kemampuan menulis, teks bahasa Arab 


\section{PENDAHULUAN}

Keterampilan menulis dalam bahasa Arab adalah salah satu kemampuan penting yang harus dimiliki oleh mahasiswa jurusan Pendidikan Bahasa Arab. Ekspresi ide atau pesan lewat tulisan akan lebih mudah dipahami oleh pembaca manakala tulisan tersebut tunduk pada struktur atau kaidah kebahasaan yang tepat. Ini disebabkan adanya kesepahaman logis yang dimiliki oleh orang yang telah memahami struktur bahasa yang tepat. Akan lebih sulit memahami tulisan berbahasa Arab yang tidak jelas aturan kaidah sintaksisnya (nahwu) dibanding tulisan yang ditulis dengan aturan nahwu yang tepat.

Kesulitan mahasiswa untuk menulis bahasa Arab yang tepat sesuai kaidah sintaksis bahasa (nahwu) diduga karena ketidakmatangan kemampuan gramatika bahasa ibu mereka (bahasa Indonesia) dalam hal ini kemampuan sintaksis. Pembelajar yang telah memiliki kompetensi sintaksis bahasa Indonesia yang baik akan lebih mudah memahami sintaksis bahasa Arab yang baik pula. Dalam teori Choamsky yang telah menghebohkan dunia dengan penemuannya pada LAD (Language Acquisition Device) yang ada pada setiap manusia. Dengan alat ini memungkinkan manusia memiliki tata bahasa universal pada otak mereka. Segala jenis bahasa didunia, dapat dengan mudah ditangkap oleh otak manusia berkat alat ini (LAD). Dapat dilihat dari setiap bayi yang lahir dapat dengan mudah beradaptasi dengan bahasa apapun yang didengarnya dari orang yang ada di sekitarnya.

\section{Konsep Universalitas Bahasa}

Kebiasaan antarmanusia dapat saling mempelajari semua bahasa di dunia membuat salah satu calon linguis besar dunia pada 1950-an, Noam Chomsky, membuat satu hipotesis bahwa basis semua bahasa di dunia adalah tata bahasa universal, yang ada dalam diri setiap orang. Hipotesis ini menyulut revolusi di riset otak manusia. Hipotesis itu berkembang pesat, dan kemudian terjadi gerakan oleh ahli bahasa (disebut "linguis") untuk mencari kaidah-kaidah keuniversalan bahasa manusia (disebut "tatabahasa universal").

Tatabahasa universal adalah kumpulan aturan, yang kemudian disimpulkan struktur setiap bahasa manusia bumi. Tata bahasa universal ini asli bawaan setiap 
manusia, tertancap erat di otak kita. Mereka membentuk matriks, kerangka semua bahasa manusia. Seandainya tidak ada tata bahasa universal ini, kemungkinan besar bahasa-bahasa di muka bumi ini akan sangat berlainan sehingga bagi manusia yang bahasanya tidak sama, tidak akan dapat saling berkomunikasi.

Pernyataan ini berkembang dari postulat competence dan performance yang diturunkan dari teori generative grammarnya Choamsky. Dalam otak anak manusia yang lahir ada bank potensi bahasa yang disebut satu sistem terwaris (an innate system). Sistem memungkinkan anak manusia menangkap bahasa apa saja yang ada disekitarnya. Potensi ini diistilahkan competence sedangkan performance adalah kemampuan untuk mengaktualisasikan potensi bahasa tersebut dalam berkomunikasi. ${ }^{1}$

\section{Keterampilan Menulis}

Konsep menulis tidak sesederhana prakteknya karena menulis bukan hanya sekedar mengubah lambang bunyi menjadi lambang grafis, sehingga orang yang lancar berbahasa lisan tidak selalu mahir menulis,menulis membutuhkan pengembangan dan penyajian pikiran secara terstruktrur. ${ }^{2}$

Karena menulis merupakan penuangan ide, pesan gagasan menggunakan simbol tulis yakni dari huruf menjadi kata kemudian menjadi kalimat sampai menjadi paragraf, sesuai aturan yang telah disepakati antara penulis dan pembaca. Untuk itu kata-kata yang digunakan itu harus disusun secara teratur dalam klausa dan kalimat mengikuti aturan baku atau standar yang dikenal dengan tata bahasa. Tulisan yang mengikuti tata bahasa yang akan lebih mudah ditangkap dan diterima oleh pikiran sang pembaca, yang kemudian disebut sistematis karena tersusun menurut suatu pola, tidak tersusun acak.

Menurut Warsito beberapa tata aturan kepenulisan yang harus dipenuhi oleh penulis agar ide,pesan yang ditulisnya dapat dengan mudah dipahami oleh orang lain, yaitu ejaan, pilihan kata atau diksi, penyusunan kalimat efektif, dan

\footnotetext{
1 . Parera, Jos Daniel.1988. Sintaksis Edisi Kedua. Jakarta : Gramedia, hal 88

2. Warsito, Tri, Tesis.2009 "Hubungan Antara Motivasi Belajar Dan Kemampuan Menyimak Dengan Keterampilan Menulis Siswa Kelas V Sekolah Dasar Sekecamatan Girimarto, h. 24
} 
pengembangan paragraf. ${ }^{3}$ Keempat unsur dapat dijelaskan secara rinci sebagai berikut:

Ejaan,konsep ejaan yang sering dikemukakan adalah pelambangan fonem dengan huruf Badudu dalam Slamet. ${ }^{4}$ Adapun pengertian ejaan sebagaimana termaktub dalam KBBI adalah kaidah-kaidah cara menggambarkan bunyi-bunyi (kata, kalimat, dsb) dalam bentuk tulisan (huruf-huruf) serta penggunaan tanda baca. ${ }^{5}$ Jika disimpulkan, maka ejaan merupakan seperangkat aturan tentang cara menuliskan bahasa dengan menggunakan huruf, kata, dan tanda baca sebagai sarananya. Adapun dalam bahasa Arab ejaan akan ditemukan lebih rumit dibandingkan dengan ejaan dalam bahasa Indonesia salah satu contohnya untuk tanda baca, tulisan bahasa Arab tidak hanya membutuhkan tanda titik (.), koma (,) tanda tanya (?) dll, namun dibutuhkan tanda syakl ( $\_,-,-$) . disamping itu ada lagi yang berbeda pada ejaan tulisan bahasa Arab yakni ada beberapa kasus kata yang hurufnya tidak dilafalkan namun pada lambang tulisnya ada atau sebaliknya ada dalam pelafalan namun tidak ada dalam tulisannya. Kaidah ini dikenal dengan ziyadah dan hazfu sebagaimana yang disebutkan oleh Yamin dalam tulisan Neli. ${ }^{6}$

Diksi, menurut Kamus Besar Bahasa Indonesia, diksi berarti "pilihan kata yang tepat dan selaras (dalam penggunaannya) untuk mengungkapkan gagasan sehingga diperoleh efek tertentu (seperti yang diharapkan).

Kalimat efektif, ciri-cirinya menurut Mc.Crimmon dalam Warsito yaitu adanya kesatuan (unity),kehematan ( economy), penekanan (emphasis), dan kevariasian (Variety). 7 Arifin menjelaskan bahwa kalimat efektif itu adalah kalimat yang memiliki kemampuan untuk menimbulkan kembali gagasan-gagasan

3. Ibid. h. 37

4 . Slamet. St. Y. 2008. Dasar-dasar keterampilan berbahasa Indonesia. Surakarta : UNS Press, h. 117

5 . Alwi Hasan,dkk. 2005. Kamus Besar Bahasa Indonesia, Jakarta : Departemen Pendidikan Nasional Balai Pustaka, h. 285

6 . Putri, Neli No. 2 Juli 2012. Problematika Menulis Bahasa Arab, Jurnal Penelitian online.Jurnal AtTa'lim Jilid 1. diakses tgl 7-09-2015) h. 174

7 . Warsito, op. cit., h.38 
pada pikiran pendengar atau pembaca seperti apa yang ada pada pikiran pembicara atau penulis. ${ }^{8}$

Sejalan dengan itu Arifin,Imam ( jurnal online, diakses 1-10-2015) menetapkan syarat kalimat efektif menjadi enam yaitu adanya : ${ }^{9}$ )Kesatuan, adalah terdapat satu ide pokok dalam kalimat. ${ }^{10}$ memiliki keseimbangan harmonis antara pikiran dan struktur bahasa yang dipakai dalam sebuah kalimat; 2) Kepaduan (koherensi) yang baik adalah hubungan timbal balik yang jelas antara unsur-unsur (kata atau kelompok yang membentuk kalimat tersebut;11 3) Keparalelan, terdapatnya unsur-unsur yang sama derajatnya, sama pola atau susunan katab dan frase yang dipakai dalam kalimat; ${ }^{12}$ 4) Ketepatan, kesesuaian atau kecocokan pemakaian unsur-unsur yang menyusun suatu kalimat agar tercipta pengertian yang bulat; 5) Kehematan, berusaha menggunakan kata yang memiliki nilai manfaat bagi pembaca, perlu dihindari penggunaan kata yang berulang-ulang; 6) kelogisan, maksudnya terdapatnya kalimat yang logis atau masuk akal sesuai dengan ejaan yang berlaku .

Pengembangan paragraf, kalimat per kalimat yang diungkapkan untuk menyusun sebuah paragraf harus memiliki hubungan makna yang logis serta sistematis dan memiliki hubungan struktur yang tepat.

\section{Ragam Keterampilan Menulis}

Kegiatan menulis membutuhkan tahapan, berdasarkan tahapan tersebut maka menulis dapat dikategorikan menjadi menulis mekanis dan menulis matang (mature writing).Tahapan mekanis adalah tahapan permulaan dari keterampilan menulis,dimana kemampuan yang bisa dilakukan pada tahap ini merealisasikan simbol-simbol bunyi bahasa menjadi huruf-huruf kongkrit. Kemudian huruf-huruf tersebut mulai dihubung-hubungkan agar menjadi kesatuan yang memiliki makna. Mature writing (menulis lanjut) yakni tahapan dimana penulis sudah mampu

8. Arifin, E Zaenal dan S Amran Tasai. 2010. Cerdas Berbahasa Indonesia, Jakarta : Akademika Pressindo, h. 97.

${ }^{9}$. Arifin, Imam Khoirun. 2013. Jurnal online, Kemampuan Siswa dalam menggunakan kalimat efektif pada karangan narasi sekolah dasar SD 15 Air Saleh Kabupaten Banyuasin, http://eprints.binadarma.ac.id diakses 1-10-2015, h.5

10 . Ibid.

11 . Ibid., 7

12. Ibid., 7 
menuangkan ide dan mengekspresikan pikiran dan perasaanya melalui tulisan yang baik, bisa memilih kata yang tepat dan menyusun kalimat yang runtut serta mampu mengembangkan paragraf dengan baik.

Adapun kategori menulis teks dalam bahasa Arab oleh Hermawan (2011) dibagi menjadi tiga yakni :131)Imla, adalah kategori menulis menekankan rupa/ postur huruf dalam membentuk kata-kat dan kalimat. 2)Kaligrafi, yaitu menulis indah (khath), kategori ini tidak hanya menekankan rupa/ postur huruf tapi juga pada aspek estetika. 3)Mengarang (Insya) kategori menulis yang berorientasi pada pengekspresian pokok pikiran, ide, perasaan ke dalam bentuk tulisan, bukan hanya visaulisasi bentuk huruf, kata, dan kalimat saja dalam hal ini wawasan dan pengalaman penulis akan sangat membantu untuk pengembangan ide.

Menurut Fachrurrozi (2011) kemampuan menulis dibagi menjadi kemampuan, yaitu: ${ }^{14}$

Pertama: Mekanis dalam bahasa Arab mencakup bentuk bahasa tulisan, seperti tanda baca, bentuk huruf,kaidah penulisan huruf-huruf yang bersambung baik dengan huruf sebelumnya tapi tidak bisa disambung dengan sesudahnya, atau huruf yang dapat disambung dengan huruf sebelum dan sesudahnya, penulisan syakal serta kaidah penulisan hamzah qatha' dan washal.

Kedua: Kemampuan mengolah nalar, kemampuan ini berkaitan dengan: a) Penggunaan bahasa dijelaskan sebagai kemampuan dalam menulis kalimat yang benar berdasarkan situasi dan kondisi yang meliputi kemampuan memilih kosa kata (mufradat),idiom, nahwu dan tarkib (struktur) ; b) Pengungkapan isi, yakni kemampuan berpikir secara kreatif dalam menyusun ide dengan tepat sesuai dengan topik; c) Keterampilan gaya bahasa, yaitu kemampuan memanipulasi kalimat maupun paragraf secara efektif; d)Keterampilan menilai, yang ini adalah kesiapan penulis untuk menulis materi yang sesuai dengan tujuan khusus menyesuaikan pikiran pembaca,mampu menyeleksi informasi yang relevan, dan mampu memilih bentuk yang sesuai untuk menuntaskan sebuah tulisan;

\footnotetext{
13. Hermawan, Acep.2011. Metodologi Pembelajaran Bahasa Arab. Bandung : Remaja Rosda Karya. h. 151

${ }^{14}$ Fachrurrozi, Aziz \& Mahyuddin,Erta.2011. Teknik Pembelajaran Bahasa Arab. Bandung: Pustaka Cendekia Utama, h. 145
} 
e)Kemampuan mengorganisasi, yaitu mampu mengungkapkan, mengorganisasikan dan menyusun pokok pikiran dengan lancar, jelas, logis serta apik.

\section{METODE}

Penelitian ini dilakukan dengan pendekatan kuantitatif dengan metode korelasi. Pada penelitian ini terdapat tiga variabel. Ketiga variabel tersebut terdiri dari satu variabel bebas yaitu penguasaan sintaksis $(\mathrm{X})$ dan dua variabel terikat yakni penguasaan nahwu (Y) dan kemampuan menulis teks Arab (Z). Penelitian ini akan menguji variabel bebas dan terikat baik secara sendiri-sendiri maupun secara bersama-sama.

Subyek penelitian ini adalah mahasiswa jurusan PBA sebanyak 115 orang. Dari jumlah ini peneliti akan mengambil sampel 30 orang mahasiswa dengan cara teknik sampel bertingkat (stratified random sampling).

Instrumen tes untuk variabel kemampuan sintaksis dan kemampuan nahwu yang berupa tes obyektif, terlebih dahulu diujicobakan kepada mahasiswa PBA sejumlah 30 orang. Ini dilakukan untuk menjamin validitas, sehingga hanya butirbutir instrumen yang memenuhi syarat yang dijadikan sebagai alat pengumpul data.

Berikut ini akan dipaparkan validitas variable dalam penelitian ini

\section{Validitas Variabel X (Kompetensi Sintaksis)}

Instrumen yang digunakan dalam penelitian ini adalah seperangkat tes sintaksis yang dikonsultasikan kepada ahli terlebih dahulu sebelum diujicobakan kepada mahasiswa jurusan PBA di luar sampel yang memiliki karakteristik sama dengan dengan sample dengan jumlah 30 orang.

Berdasarkan hasil analisis butir instrumen soal untuk mengambil data kemampuan sintaksis yang diujicobakan dengan rumus tersebut dapat dijelaskan bahwa dari 30 butir soal, yang dinyatatkan valid hanya 21 item, dimana ada 7 butir item yang tidak dapat digunakan. Dengan demikian hanya 21 butir item soal yang digunakan untuk mengambil data untuk kompetensi sintaksis.

\section{Validitas Variabel Y (Kompetensi Nahwu)}


Instrumen soal kompetensi Nahwu yang diujicobakan pada 30 orang mahasiswa PBA, setelah uji pakar dari 35 item soal ada dua soal yang tidak layak sehingga sisa item soal tinggal 33 item, berdasarkan hasil uji validitas dengan menggunakan uji korelasi product moment, maka diperoleh sebanyak 30 item soal yang dinyatakan valid dan dinyatakan dapat digunakan untuk mengambil data untuk kompetensi nahwu.

\section{Variabel Z (Keterampilan menulis Arab)}

Instumen keterampilan menulis teks bahasa Arab yang peneliti gunakan adalah seperangkat soal insya muwajjaha (menulis terbimbing) dalam bentuk soal essay. Validasi instrumen ini dengan uji pakar yang dikonsultasikan kepada dosen Insya (keterampilan menulis Arab) di jurusan PBA FTIK IAIN Pontianak.

Setelah uji validitas, instrumen kompetensi sintaksis juga diuji reliabilitasnya untuk menentukan terpercaya atau tidaknya instrument tes tersebut. Pada penelitian ini uji reliablitas dilakukan dengan uji coba satu kali tes pada mahasiswa jurusan PBA dengan jumlah responden 30 orang. Data dari hasil uji coba dianalisis dengan mencari jumlah varian di setiap butir pertanyaan dan varian totalnya. Setelah varian butir dan varian total didapat maka dilakukan uji reliabilitas dengan rumus alpha sebagai berikut:

$$
\alpha=\left(\frac{K}{K-1}\right)\left(\frac{s_{r}^{2}-\Sigma s_{i}^{2}}{s_{x}^{2}}\right)
$$

Hasil analisis uji realibilitas untuk instrumen kompetensi sintaksis dengan menggunakan software SPSS dapat dilihat pada tabel berikut :

Reliability Statistics

\begin{tabular}{|r|r|}
\hline \multicolumn{1}{|c|}{$\begin{array}{c}\text { Cronbach's } \\
\text { Alpha }\end{array}$} & N of Items \\
\hline .537 & 30 \\
\hline
\end{tabular}

Keterangan:

1) Apabila nilai Alpha > rtabel, maka data dikatakan reliable. Begitu pula sebaliknya, jika nilai Alpha < rtabel, maka data dikatakan tidak reliabel. 2) Nilai Alpha 0,537. 
3) $\mathrm{N}=30$, maka nilai rtabel dengan taraf signifikansi 0,05 adalah 0,361.4) Dengan demikian alpha > rtabel, dapat disimpulkan bahwa data dapat dikatakan reliabel.. 5) Kriteria Reliabilitas :

$\begin{array}{lll}\text { No } & \text { Reliabilitas } & \text { Kategori } \\ \text { 1. } & 0,800-1,000 & \text { Sangat tinggi } \\ \text { 2. } & 0,600-0,799 & \text { Tinggi } \\ \text { 3. } & 0,400-0,500 & \text { Cukup } \\ \text { 4. } & 0,200-0,399 & \text { Rendah } \\ \text { 5. } & >0,200 & \text { Sangat rendah }\end{array}$

Maka dapat disimpulkan tes ini memiliki tingkat reliabilitas tinggi.

\section{Reliabilitas Variabel Y (Kompetensi Nahwu)}

Uji Reliablitas untuk instrumen 33 soal kompetensi nahwu setelah uji validitas dilakukan dapat dilihat hasilnya dengan rumus alpha sebagai berikut:

\begin{tabular}{|r|r|}
\multicolumn{1}{c|}{ Reliability Statistics } \\
\hline $\begin{array}{c}\text { Cronbach's } \\
\text { Alpha }\end{array}$ & $\begin{array}{c}\text { N of } \\
\text { Items }\end{array}$ \\
\hline .907 & 33 \\
\hline
\end{tabular}

\section{Keterangan:}

1) Apabila nilai Alpha > rtabel, maka data dikatakan reliable. Begitu pulasebaliknya, jika nilai Alpha < rtabel, maka data dikatakan tidak reliabel. 2) Nilai Alpha 0,907. 3) $\mathrm{N}=30$, maka nilai rtabel dengan taraf signifikansi 0,05 adalah 0,361. 4) Dengan demikian alpha > rtabel, dapat disimpulkan bahwa data dapat dikatakan reliabel. 5) Kriteria Reliabilitas :

\begin{tabular}{|c|c|c|c|}
\hline No & Reliabilitas & & Kategori \\
\hline 1 & $0,800-1,000$ & : & Sangat tinggi \\
\hline 2 & $0,600-0,799$ & & Tinggi \\
\hline 3 & $0,400-0,500$ & Cukup & \\
\hline 4 & $0,200-0,399$ & : & Rendah \\
\hline 5 & $>0,200$ & Sangat & rendah \\
\hline
\end{tabular}

Berdasarkan hasil analisis uji reliabilitas tersebut di atas maka dapat disimpulkan tes kompetensi nahwu ini memiliki tingkat reliabilitas sangat tinggi.

Berdasarkan bentuk variabel dari penelitian ini maka selanjutnya model analisis yang digunakan untuk menganalisa datanya adalah model analisis jalur (path analize). Analisis jalur ialah suatu teknik untuk menganalisis hubungan sebab akibat yang tejadi pada regresi berganda jika variabel bebasnya 
mempengaruhi variabel tergantung tidak hanya secara langsung tetapi juga secara tidak langsung”. (Robert D. Retherford 1993)..Teknik ini digunakan untuk menguji besarnya sumbangan (kontribusi) yang ditunjukkan oleh koefisien jalur pada setiap diagram jalur dari hubungan kausal antar variabel $\mathrm{X}_{1} \mathrm{X}_{2}$ dan $\mathrm{X}_{3}$ terhadap $\mathrm{Y}$ serta dampaknya terhadap Z.

Rumus persamaan analisis data yang akan digunakan untuk menganalisis variabel-variabel penelitian ini adalah

$$
\begin{aligned}
& \mathrm{Y} 1: \lambda 1.1 \mathrm{X} 1+\zeta 1 \\
& \mathrm{Y} 2: \lambda 1.2 \mathrm{X} 1+\beta 1.1 \mathrm{Y} 1+\zeta 2
\end{aligned}
$$

\section{HASIL PENELITIAN}

\section{Karakteristik Responden}

Karakteristik responden dapat membantu memperoleh gambaran mengenai kecenderungan prilaku responden yang terpilih dalam penelitian ini berdasarkan jenis kelamin, latar belakang pendidikan.

\section{Karakteristik responden berdasarkan jenis kelamin}

Tabel 1: Jenis Kelamin

\begin{tabular}{|l|l|l|}
\hline Jenis Kelamin & Frekuensi & Persentase \\
\hline Perempuan & 24 & $80 \%$ \\
\hline Laki-laki & 6 & $20 \%$ \\
\hline Total & $\mathbf{3 0}$ & $\mathbf{1 0 0}$ \\
\hline
\end{tabular}

\section{Karakteristik responden berdasarkan latar belakang pendidikan}

Tabel 2: Latar Belakang Pendidikan

\begin{tabular}{|l|l|l|l|}
\hline Pendidikan & Kategori & Frekuensi & Persentase \\
\hline SMA & Pondok Pesantren & 1 & $3,3 \%$ \\
\hline SMK /SMA & Umum & 6 & $20 \%$ \\
\hline MA & Bukan Pondok Pesantren & 10 & $33,3 \%$ \\
\hline MA & Pondok Pesantren & 11 & $36,7 \%$ \\
\hline MA & Pondok Salaf & 2 & $6,7 \%$ \\
\hline Total & & $\mathbf{3 0}$ & $\mathbf{1 0 0} \%$ \\
\hline
\end{tabular}

Dari tabel di atas dapat dideskripsikan bahwa ada 1 orang responden yang berlatar belakang SMA yang dikelola oleh pondok pesantren artinya 
siswa di lembaga pendidikan tersebut mempelajari pelajaran umum termasuk pelajaran bahasa Indonesia dan pelajaran ilmu agama termasuk bahasa Arab.

Sedangkan responden yang berasal dari SMA dengan kategori sekolah umum ada 5 orang, di mana diketahui di SMA umum ada yang belum memberlakukan pelajaran bahasa Arab sebagai bagian dari kurikulumnya, walaupun sudah diberlakukan, namun materinya belum mendalam. Adapun jumlah responden yang berasal dari MA yang bukan pondok ada 8 orang. Sementara itu responden untuk yang berlatar belakang pendidikan MA pondok pesantren juga ada 8 orang, dan sisanya 2 orang berlatar belakang pendidikan pondok pesantren salaf, di mana tidak diajarkan pelajaran umum termasuk bahasa Indonesia. Berdasarkan tabel di atasdapat digambarkan keadaan sekolah responden sebelum masuk jurusan PBA, yaitu responden yang tidak mempelajari bahasa Arab secara intensif yaitu dari SMA umum dan MA bukan pondok berjumlah 16 orang atau 53,3\%, sedangkan yang belajar secara intensif ada 46,7. Sedangkan yang tidak pernah belajar bahasa Arab tapi belajar bahasa Indonesia atau dari SMA umum ada 6 orang atau $20 \%$, sebaliknya mahasiswa yang tidak belajar bahasa Indonesia tapi belajar bahasa Arab ada 2 orang atau 6,7\%. Sedangkan yang belajar kedua bahasa tersebut dapat disimpulkan 22 orang atau 73,3 \%. Kemudian dibagi lagi menjadi dua kelompok yaitu kelompok yang pernah belajar bahasa Arab ada 24 orang atau $80 \%$, sisanya 6 orang atau $20 \%$ tidak pernah belajar bahasa Arab.

\section{Karakteristik responden berdasarkan tahun masuk kuliah}

Tabel 3: Tahun masuk kuliah responden

\begin{tabular}{|l|l|l|l|}
\hline No. & Tahun masuk kuliah & F & \% \\
\hline 1. & $2013 / 2014$ & 20 & 66,6 \\
\hline 2. & $2014 / 2015$ & 10 & 33,3 \\
\hline
\end{tabular}

Berdasarkan tabel di atas dapat digambarkan karakteristik responden bahwa berdasarkan tahun masuk kuliah di jurusan PBA Fakultas Tarbiyah dan Ilmu keguruan IAIN Pontianak tersebut dapat diketahui bahwa mereka telah pernah memprogramkan mata kuliah Bahasa Indonesia, mata kuliah Nahwu I dan II, serta mata kuliah Insya I dan II. Untuk mahasiswa yang masuk pada tahun 2013/2014 berarti mereka telah duduk di semester V pada tahun 
akademik 2015/2016, sementara itu yang masuk pada tahun 2014/2015, mahasiswa tersebut sudah duduk di semester III pada tahun akademik yang sama. Mata kuliah Bahasa Indonesia telah diprogramkan pada semester I, untuk mata kuliah Nahwu I diprogramkan pada semester II, sedangkan mata kuliah Nahwu II diberikan pada semester III. Adapun mata kuliah Insya I diberikan pada semester III, dan Insya II pada semester IV. Jadi dapat disimpulkan bahwa seluruh responden telah pernah mendapatkan materi perkuliahan bahasa Indonesia, Nahwu dan Insya (menulis Bahasa Arab).

Analisis data penelitian ini dengan menganalisa 3 variabel, dimana 2 variabel independet dan 1 variabel dependent dengan menggunakan analisis jalur (Path Analysis) menggunakan Software SmartPLS 3.0 I. Analisis jalur merupakan perluasan dari model regresi linier berganda yang merupakan salah satu alat analisis statistik yang digunakan untuk menguji pengaruh dari beberapa variabel bebas terhadap lebih dari satu variable terikat (Multiviarate) yang melibatkan variable mediasi atau variable intervening (variabel antara). Karena ukuran sampel kurang dari 100 dapat dilakukan dengan menggunakan software SPSS atau SmartPLS (path dengan pendekatan non parametrik) karena software Amos didesain untuk data dengan jumlah sampel minimal 100, hal ini terkait dengan metode estimasi yang dilakukan dalam software Amos menggunakan Maximum Likelihood Estimation (MLE) yang dengan syarat jumlah sampel minimal 100.

Analisis jalur dilakukan dengan cara mengkonstruksi model penelitian dalam diagram jalur (path diagram) ke dalam software SmartPLS 3.0. Perhitungan analisis jalur dalam penelitian ini dilakukan berdasarkan data sekunder yang diperoleh, kemudian diolah menggunakan bantuan software SmartPLS versi 3.0 for Windows. Setelah dilakukan analisis jalur menggunakan SmartPLS diperoleh output analisis yang meliputi uji ketepatan model $\left(\mathrm{R}^{2}\right.$ dan $\left.\mathrm{Q}^{2}\right)$, pengaruh variabel bebas secara simultan dan secara parsial (Uji t) terhadap variabel terikat.

Untuk melihat seberapa tepat atau seberapa akurat prediksi yang dihasilkan oleh analisis jalur, dapat dilihat dari beberapa kriteria diantaranya nilai $\mathrm{R}^{2}$ yang mendekati 1 , serta standar error yang kecil menunjukkan bahwa hasil prediksi analisis jalur semakin tepat atau mendekati sempurna. Penilaian 
ketepatan model analisis jalur dapat dilihat dari ouput SmartPLS 3.0 sebagai berikut:

Tabel 4: Penilaian Ketepatan Model Analisis Jalur Koefisien Determinasi $\left(\mathrm{R}^{2}\right)$

\begin{tabular}{|c|c|}
\hline Model & R \\
\hline $\mathrm{Y}$ & 0.022 \\
\hline $\mathrm{Z}$ & 0.287 \\
\hline
\end{tabular}

Sumber: $\quad$ Data Sekunder diolah menggunakan Software SmartPLS 3.0 for Windows, Tahun 2015.

Berdasarkan kriteria ketepatan model yang diperoleh dari hasil analisis analisis jalur dengan bantuan software SmartPLS 3.0, diperoleh: 1) Koefisien determinasi $\left(\mathrm{R}^{2}\right)$ untuk model 1: sebesar 0,022 atau 2,2\%. Artinya: Variansi Penguasaan Ilmu Nahwu dapat dijelaskan oleh variasi Sintaksis hanya sebesar 2,2\% sedangkan sisanya sebesar 97,8\% variasi Penguasaan ilmu nahwu dijelaskan oleh variabel lain yang tidak terdapat di dalam penelitian ini. 2) Koefisien determinasi $\left(\mathrm{R}^{2}\right)$ untuk model 2: sebesar 0,287 atau 28,7\%. Artinya: Variansi perubahan Kemampuan Menulis dalam Bahasa Arab dapat dijelaskan oleh Sintaksis dan Penguasaan Ilmu Nahwu sebesar 28,70\% sedangkan sisanya sebesar 71,30\% variasi kemampuan menulis dijelaskan oleh variabel lain yang tidak terdapat di dalam penelitian ini.

Estimasi Pengaruh Langsung Secara Parsial Antar Variabel Bebas terhadap Variabel Terikat dapat dilihat pada Kriteria penerimaan atau penolakan hipotesis berdasarkan nilai T-Statistik dan P-Value, jika nilai Probabilitas (P), jika nilai $\mathrm{P}<$ alpha $(\mathrm{P}<0.05)$ maka hipotesis statistik $\left(\mathrm{H}_{0}\right)$ ditolak, artinya: Variabel bebas berpengaruh signifikan terhadap variabel terikat dan sebaliknya jika P>0.05 maka hipotesis statistik $\left(\mathrm{H}_{0}\right)$ diterima, artinya: Variabel bebas tidak berpengaruh signifikan terhadap variabel terikat. Hasil perhitungan software SmartPLS 3.0 sebagai berikut.

Tabel 5: Nilai Koefisien Parameter Jalur (Pengaruh Langsung)

\begin{tabular}{|c|c|c|c|}
\hline Variabel & Faktor Loading & T Statistics & P-Values \\
\hline $\mathbf{X}->$ Y & -0.148 & 0.868 & 0.387 \\
\hline $\mathbf{X}->\mathbf{Z}$ & 0.524 & 3.626 & 0.000 \\
\hline Y $>$ Z & 0.214 & 1.229 & 0.221 \\
\hline
\end{tabular}

Sumber: Data Sekunder diolah menggunakan Software SmartPLS 3.0 for Windows, Tahun 2015.

Berdasarkan Tabel di atas diperoleh- nilai t hitung ( $\mathrm{t}$ test) sebagai berikut : pertama: Diperoleh nilai koefisien parameter jalur antara antara Sintaksis dengan 
Penguasaan Ilmu Nahwu sebesar -0,148 dengan nilai T-Statistik sebesar 0,868 dan P-Values sebesar 0,387, karena P>0.05, maka Hipotesis Nol $\left(\mathrm{H}_{0}\right)$ diterima, artinya: Tidak terdapat pengaruh langsung yang signifikan antara Penguasaan Sintaksis terhadap Pengusaaan Nahwu. Kedua: Diperoleh nilai koefisien parameter jalur antara antara Sintaksis dengan Kemampuan Menulis Bahasa Arab sebesar 0,524 dengan nilai T-Statistik sebesar 3,626 dan P-Values sebesar 0,00, karena $\mathrm{P}<0.05$, maka Hipotesis Nol $\left(\mathrm{H}_{0}\right)$ ditolak, artinya: Terdapat pengaruh langsung yang signifikan antara Sintaksis terhadap Kemampuan Menulis. Ketiga: Diperoleh nilai koefisien parameter jalur antara antara Penguasaan Ilmu Nahwu dengan Kemampuan Menulis Bahasa Arab sebesar 0,214 dengan nilai T-Statistik sebesar 1,229 dan P-Values sebesar 0,221, karena $\mathrm{P}>0.05$, maka Hipotesis $\mathrm{Nol}\left(\mathrm{H}_{0}\right)$ diterima, artinya: Tidak terdapat pengaruh langsung yang signifikan antara Kemampuan Nahwu terhadap Kemampuan Menulis Bahasa Arab. Keempat: Variabel yang berpengaruh paling dominan pengaruhnya terhadap kemampuan menulis adalah Sintaksis karena memiliki nilai koefisien parameter paling tinggi dibandingkan dengan variabel lain, yaitu sebesar 0,524.

Estimasi terhadap Pengaruh Tidak Langsung dan Pengaruh Total, dapat dilihat pada tabel berikut :

Tabel 6: Pengaruh Tidak Langsung Antara Variabel Bebas terahdap Variabel Terikat

\begin{tabular}{|c|c|c|l|}
\hline Variabel & Faktor Loading & $\begin{array}{l}\text { T } \\
\text { Statistik }\end{array}$ & $\begin{array}{l}\text { P } \\
\text { Values }\end{array}$ \\
\hline $\mathbf{X}->\mathbf{Z}$ & -0.032 & 0.560 & 0.577 \\
\hline
\end{tabular}

Sumber: Data Sekunder diolah menggunakan Software SmartPLS 3.0 for Windows, Tahun 2015.

Berdasarkan hasil perhitungan SmartPLS 3.0 pada tabel Dapat diketahui seberapa besar pengaruh tidak langsung antara variabel Sintaksis yang dimediasi oleh Penguasaan Nahwu terhadap Kemampuan menulis. Diperoleh faktor loading sebesar -0,032 dengan $\mathrm{T}$ statistik sebesar 0,560 dengan P-Values sebesar 0,577, karena P-Values $>0,05$, maka H0 diterima, artinya: Kemampuan menulis bahasa Arab yang dimediasi oleh variabel penguasaan nahwu tidak berpengaruh signifikan terhadap kemampuan menulis bahasa Arab. Artinya: Kemampuan sintaksis berpengaruh signifikan terhadap kemampuan menulis Arab, namun 
setelah melalui variabel antara (dimediasi) oleh penguasaan nahwu justru memperlemah pengaruh Sintaksis terhadap kemampuan menulis bahasa Arab.

Estimasi Pengaruh total antara sintaksis dan penguasaan nahwu terhadap kemampuan menulis

Tabel 7: Total Pengaruh Variabel Bebas terahdap Variabel Terikat

\begin{tabular}{|c|c|c|c|}
\hline Variabel & Faktor Loading & $\begin{array}{c}\text { T } \\
\text { Statistik }\end{array}$ & $\begin{array}{c}\mathbf{P} \\
\text { Values }\end{array}$ \\
\hline $\mathbf{X}>\mathbf{Y}$ & -0.148 & 0.868 & 0.387 \\
\hline $\mathbf{X}->\mathbf{Z}$ & 0.493 & 3.197 & 0.002 \\
\hline $\mathbf{Y ~}>\mathbf{Z}$ & 0.214 & 1.229 & 0.221 \\
\hline
\end{tabular}

Sumber: Data Sekunder diolah menggunakan Software SmartPLS

3.0 for Windows, Tahun 2015.

Berdasarkan hasil perhitungan SmartPLS 3.0 pada tabel dapat diketahui seberapa besar total pengaruh variable bebas terhadap variable terikat. Maka, dapat diinterpretasikan bahwa: Total pengaruh penguasaan Sintaksis secara bersama-sama dengan pengaruh variabel penguasaan nahwu terhadap Kemampuan menulis sebesar 0,493 dengan $T$ statistic sebesar 3,197 dengan tingkat P-Values sebesar 0,002, karena P-Values <0.05, maka H0 ditolak, artinya: Terdapat pengaruh yang signifikan secara bersama-sama antara variabel Sintaksis dan Variabel Pengusaan Nahwu terhadap Kemampuan Menulis.

Selanjutnya untuk memperkuat hasil perhitungan pengaruh total pada analisis SmartPLS 3.0 di atas, dilakukan uji pengaruh secara simultan melalui analisis regresi menggunakan software SPSS 18.0 for windows, dengan hasil sebagai berikut:

Tabel 8: Uji Pengaruh Secara Simultan

\begin{tabular}{|l|r|r|r|r|r|}
\hline \multicolumn{1}{|c|}{ Model } & $\begin{array}{c}\text { Jumlah } \\
\text { Kuadrat }\end{array}$ & $\begin{array}{c}\text { Derajat } \\
\text { Bebas }\end{array}$ & $\begin{array}{c}\text { Akar Rata- } \\
\text { rata }\end{array}$ & F & $\begin{array}{c}\text { Signifikansi } \\
\text { Probilitas }\end{array}$ \\
\hline Regresi & 3813.432 & 2 & 1906.716 & 5.447 & 0.010 \\
\hline Sisaan & 9451.026 & 27 & 350.038 & & \\
\hline Total & 13264.458 & 29 & & & \\
\hline
\end{tabular}

Berdasarkan tabel Analisis variansi regresi linear berganda pada tabel Dapat diketahui besar pengaruh secara simultan (bersama-sama) antara variabel bebas terhadap variabel terikat. Diperoleh nilai F statistic sebesar 5,447 dengan signifikansi probabilitas sebesar 0,01, karena Signifikansi <0.05, maka H0 ditolak, 
artinya: Terdapat pengaruh yang signifikan secara simultan antara variabel Sintaksis dan variabel Penguasaan Nahwu terhadap Kemampuan Menulis. Interpretasi Terhadap Model Analisis Jalur

Koefisien parameter jalur ( $\beta$ ) pada Tabel 4.2 dapat disusun ke dalam persamaan analisis jalur (path model) sebagai berikut:

$$
\begin{aligned}
& Y=-0,148 X \\
& Z=0,524 X+0,214 Y
\end{aligned}
$$

Interpretasi dari persamaan di atas adalah sebagai berikut: interpretasi pertama menunjukkan bahwa koefisien parameter jalur antara variabel penguasaan Sintaksis terhadap Penguasaan Nahwu sebesar -0,148, artinya: Jika variabel Sintaksis meningkat 1 poin maka akan berdampak tidak signifikan terhadap turunnya (karena tandanya negatif) Pengusahaan Nahwu sebesar 0,148 poin, dengan asumsi variabel lain yang mempengaruhinya konstan.

Interpretasi kedua menunjukkan bahwa koefisien parameter jalur antara variabel Sintaksis terhadap Kemampuan Menulis bahasa Arab sebesar 0,524, artinya: Jika variabel Sintaksis meningkat 1 poin maka akan berdampak signifikan terhadap meningkatnya (karena tandanya positif) Kemampuan Menulis sebesar 0,524 poin, dengan asumsi variabel lain yang mempengaruhinya konstan.

Interpretasi ketiga menunjukkan bahwa koefisien parameter jalur antara variabel Penguasaan Nahwu terhadap Kemampuan Menulis bahasa Arab sebesar 0,214, artinya: Jika variabel Penguasaan Nahwu meningkat 1 poin maka akan berdampak tidak signifikan terhadap peningkatan (karena tandanya positif) Kemampuan Menulis Bahasa Arab sebesar 0,214 poin, dengan asumsi variabel lain yang mempengaruhinya konstan.

\section{HASIL PENELITIAN}

Berdasarkan hasil analisis penelitian di atas, maka dapat diperoleh kesimpulan sebagai berikut : Hubungan antara penguasaan sintaksis dengan penguasaan nahwu berdasarkan analisis Software Smart PLS 3.0 for Windows Tahun 2015,diperoleh nilai koefisien parameter jalur antara antara Sintaksis dengan Penguasaan Ilmu Nahwu sebesar -0,148 dengan nilai T-Statistik sebesar 0,868 dan P-Values sebesar 0,387, karena $\mathrm{P}>0.05$, maka Hipotesis $\operatorname{Nol}\left(\mathrm{H}_{0}\right)$ 
diterima, artinya: tidak terdapat hubungan langsung yang signifikan antara Penguasaan Sintaksis terhadap Pengusaaan Nahwu. Interpretasinya jika variabel Sintaksis meningkat 1 poin maka akan berdampak tidak signifikan terhadap turunnya (karena tandanya negatif) Pengusahaan Nahwu sebesar 0,148 poin, dengan asumsi variabel lain yang mempengaruhinya konstan.

Beradasarkan analisis Software SmartPLS 3.0 for Windows Tahun 2015,diperoleh nilai koefisien parameter jalur antara antara variabel Sintaksis dengan Kemampuan Menulis Bahasa Arab sebesar 0,524 dengan nilai T-Statistik sebesar 3,626 dan P-Values sebesar 0,00, karena $\mathrm{P}<0.05$, maka Hipotesis $\mathrm{Nol}\left(\mathrm{H}_{0}\right)$ ditolak, artinya: Terdapat hubungan langsung yang signifikan antara Sintaksis terhadap Kemampuan Menulis. Sehingga interpreasinya jika variabel Sintaksis meningkat 1 poin maka akan berdampak signifikan terhadap meningkatnya Kemampuan Menulis sebesar 0,524 poin, dengan asumsi variabel lain yang mempengaruhinya konstan.

Dari hasil analisis analisis Software SmartPLS 3.0 for Windows Tahun 2015, diperoleh nilai koefisien parameter jalur antara antara Penguasaan Ilmu Nahwu dengan Kemampuan Menulis Bahasa Arab sebesar 0,214 dengan nilai TStatistik sebesar 1,229 dan P-Values sebesar 0,221, karena P>0.05, maka Hipotesis Nol $\left(\mathrm{H}_{0}\right)$ diterima, artinya: Tidak terdapat hubungan langsung yang signifikan antara Kemampuan Nahwu terhadap Kemampuan Menulis Bahasa Arab. Sehingga interpretasinya dapat dijelaskan bahwa jika variabel Penguasaan Nahwu meningkat 1 poin maka akan berdampak tidak signifikan (karena tandanya positif) terhadap peningkatan Kemampuan Menulis Bahasa Arab sebesar 0,214 poin, dengan asumsi variabel lain yang mempengaruhinya konstan.

Berdasarkan analisis Software SmartPLS 3.0 for Windows, Tahun 2015, Total pengaruh penguasaan Sintaksis secara bersama-sama dengan pengaruh variabel penguasaan nahwu terhadap Kemampuan menulis sebesar 0,493 dengan T statistic sebesar 3,197 dengan tingkat P-Values sebesar 0,002, karena P-Values <0.05, maka H0 ditolak, artinya: Terdapat pengaruh yang signifikan secara bersama-sama antara variabel Sintaksis dan Variabel Pengusaan Nahwu terhadap Kemampuan Menulis. 


\section{PEMBAHASAN HASIL PENELITIAN}

\section{Hubungan antara penguasaan sintaksis dan penguasaan nahwu}

Berdasar pada hasil analisis statistik dimana H0 diterima menunjukkan tidak terdapat hubungan yang positif antara Penguasaan sintaksis memiliki hubungan negatif dengan penguasaan nahwu. Hasil temuan peneliti memberi indikasi bahwa ada variasi lain yang turut berpengaruh pada hubungan tersebut.

Pada teori linguistik dua aliran yang mendominasi adalah aliran structural yang dipelopori oleh Ferdinan de Saussure (1857-1913) dan aliran transformatif yang dipelopori oleh Noam Chomsky. Aliran struktural berpandangan bahwa: a) Bahasa itu adalah ungkapan lisan; b)Kemampuan berbahasa itu diperoleh melalui kebiasaan yang ditunjang dengan latihan dan penguatan; c)Setiap bahasa memiliki sistemnya sendiri yang berbeda dari bahasa lainnya,oleh karena itu menganalisis suatu bahasa tidak bisa memakai kerangka untuk menganalisa bahasa lainnya; d)Setiap bahasa memiliki sistem yang utuh dan cukup untuk mengekspresikan maksud penuturnya, oleh karena itu tidak ada bahasa yang unggul dari bahasa lainnya; e) Semua bahasa yang hidup berkembang mengikuti perubahan zaman terutama karena terjadinya kontak dengan bahasa lain. Oleh karena itu, kaidahkaidahnya pun bisa mengalami perubahan; f) Sumber pertama dan utama kebakuan bahasa adalah penutur bahasa tersebut, bukan lembaga ilmiah, pusat bahasa, atau mazhab-mazhab gramatika.

Berdasarkan teori- teori tersebut yang bisa disesuaikan dengan hasil penelitian ini adalah bahwa bahasa itu adalah pembiasaan yang butuh pada latihan dan penguatan,peneliti berusaha mencari titik temu teori ini dengan hasil penelitian yang mendeskripsikan bahwa tidak ada hubungan yang positif antara penguasaan sintaksis dan penguasaan nahwu, dengan mengambil data melalui teknik wawancara langsung kepada beberapa responden yang nilai nahwunya berkategori baik, namun nilai sintaksisnya berada pada kategori kurang baik, dari hasil wawancara peneliti mengetahui bahwa mereka yang nilai sintaksisnya rendah karena kurang pemahaman sintaksis, melainkan kurang penguatan atau latihan, bahkan beberapa responden tersebut menjawab tidak pernah belajar tata bahasa Indonesia sama sekali karena latar belakang pendidikan mereka adalah 
pondok salaf, dimana tidak terapkannya mata pelajaran umum di pondok tersebut termasuk bahasa Indonesia.

Dalil berikutnya adalah bahwa aliran struktural yang menekankan adanya perbedaan system antara satu bahasa dengan bahasa lainnya, sementara itu aliran transformatif-generatif menegaskan adanya banyak unsur kesamaan di antara bahasa-bahasa. Namun secara tidak langsung pada teori kedua tetap diakui adanya perbedaan, karena sisi yang sama pada bahasa hanya pada tataran struktur dalamnya, tapi struktur luar tetap berbeda. Teori transformatif-generatif memisahkan bahasa atas dua lapisan, yakni: deep structure (struktur dalam/ lapis batin) yaitu tempat terjadinya proses berbahasa yang sesungguhnya/ secara mentalistik; dan surface structure (struktur luar, struktur lahiriah) yaitu wujud lahiriyah yang ditransformasikan dari lapis batin. Contoh: Welcome, Ahlan wa Sahlan, Selamat datang merupakan tiga unsur struktur permukaan yang ditransformasikan dari satu struktur dalam yang sama.

\section{Hubungan langsung antara penguasaan sintaksis dengan kemampuan menulis teks bahasa Arab}

Hubungan antar kedua variabel ini HO ditolak dengan nilai koefisien parameter 0,524 sehingga pengaruh kompetensi sintaksis menjadi dominan terhadap keterampilan menulis ini memperkuat teori bahwa ada hubungan yang signifikan antara kompetensi bahasa dan performansi bahasa, yakni penguasaan sintaksis merupakan kompetensi bahasa dan kemampuan menulis merupakan performansi bahasa. Performansi merupakan manifestasi nyata kompetensi kebahasaan seseorang tinggi rendahnya kompetensi kebahasaan seseorang tercermin pada keterampilan berbahasanya. 15

\section{Hubungan antara penguasaan Nahwu dengan kemampuan menulis teks bahasa Arab}

Terdapat hubungan antara penguasaan Nahwu dengan kemampuan menulis teks bahasa Arab namun hubungan ini tidak signifikan, kemungkinan pemahaman nahwu mahasiswa adalah pemahaman teoritis bukan pemahaman praktis atau terapan sehingga pemahaman tersebut belum bisa menguatkan

15 . Nurgiyantoro, Burhan. 2001. Penilaian Dalam Pengajaran Bahasa Dan Sastra. Yogyakarta: BPFE Yogyakarta.h. 167 
kemampuannya dalam menulis teks bahasa Arab. Untuk kepentingan praktis ini pengajar bahasa termasuk bahasa Arab perlu menyusun bahan pembelajaran Insya (keterampilan menulis) tanpa melupakan qawaid (tata bahasa) bahasa Arab,dalam hal ini dikenal sebagai tata bahasa pedagogis.

\section{Hubungan secara bersama-sama antara variabel penguasaan sintaksis,nahwu dan kemampuan menulis teks Arab.}

Jika dilihat dari signifikansi probabilitas sebesar 0,01, karena Signifikansi $<0.05$, maka H0 ditolak, artinya terdapat hubungan secara bersama-sama antara penguasaan sintaksis dengan penguasaan nahwu dan kemampuan menulis teks Arab. Keterampilan menulis teks bahasa Arab membutuhkan kompetensi kebahasaan yang memadai. Ini membuktikan teori innatenya Choamsky bahwa manusia memiliki kompetensi bahasa secara bawaan, kompetensi tersebut adalah deep structure dan akan dibutuhkan untuk dalam mengejawantahkannnya dalam bentuk performansi keterampilan menulis. Dengan bantuan struktur bahasa penulis akan bisa mengatur dan menggunakan kata, kalimat dengan sistematis dan mempermudah pembaca untuk memahami pesan dan ide yang ingin disampaikan oleh penulis. Hal ini sejalan dengan apa yang dijelaskan oleh Warsiman bahwa ketika sesorang hendak menghasilakn ujaran (lisan ataupun tulisan) maka ia harus melibatkan operasi-operasi kognitifnya dalam hal ini adalah tata bahasa agar ujaran tersebut butir-butir leksikalnya cocok dan tepat secara sintaksis. ${ }^{16}$ Ini diperkuat oleh hasil penelitian yang memperlihatkan adanya hubungan yang signifikan antara kemampuan memahami struktur dengan kemampuan menulis eksplanasi yang telah dilakukan oleh Sihombing, Afriyanti. ${ }^{17}$ Namun jika dilihat dari analisa data di atas terlihat bahwa variable sintaksis mendominasi dibanding variable nahwu karena koefisien parameternya paling tinggi dibandingkan dengan variabel lain, yaitu sebesar 0,524. Artinya mahasiswa yang memiliki kemampuan sintaksis yang bagus menunjukkan keterampilan yang baik pula dalam menulis teks bahasa Arab.

\footnotetext{
${ }^{16}$ Warsiman, 2011,Keterkaitan Bahasa Bahasa dan Logika Dalam Berpikir Kritis. Jurnal Prosodi, volume V Nomor 1 Januari 2011. Online, http://journal.trunojoyo.ac.id/prosodi/issue/view/15, diakses 25-11-2015, h. 3

${ }^{17}$. Sihombing, Afriyanti,Skripsi. 2015.Pengaruh Pemahaman Struktur dan Ciri kebahasaan Teks Eksplanasi Kompleks Terhadap Kemampuan Menulis teks Eksplanasi Kompleks oleh siswa kelas xi sma negeri 20 Medan Tahun pembelajaran 2014/2015. Medan : Digital Library.
} 
Pada kompetensi menulis dibutuhkan kemampuan mengorganisasikan kalimat yang logis. Kemampuan mengorganisasi, yaitu mampu mengungkapkan, mengorganisasikan dan menyusun pokok pikiran dengan lancar, jelas, logis serta apik. ${ }^{18}$ Kemampuan ini adalah kemampuan penalaran, dari sini bisa dilihat bahwa mahasiswa Indonesia yang memiliki bakat menalar pada tata bahasa Indonesia mampu mengembangkan kalimat yang logis dalam menulis. Mahasiswa jurusan PBA IAIN Pontianak yang memiliki penguasaan tata bahasa sintaksis yang baik akan memiliki tata bahasa internal yang kuat sehingga mampu memproduksi bahasa yang logis.Pemaparan ilmiah membutuhkan unsur-unsur yang semuanya harus logis (mantis), unsur-unsur tersebut mencakup pilihan kata, struktur kalimat,paragraph serta wacananya. ${ }^{19}$ Keutamaan bahasa adalah kebermaknaan dan memiliki fungsi komunikatif yang baik. ${ }^{20}$

\section{KESIMPULAN}

Penguasaan sintaksis dan penguasaan nahwu tidak menunjukkan adanya hubungan yang signifikan, hal ini disebabkan adanya variasi lain yang turut berpengaruh pada kedua hubungan tersebut, seperti pembiasaan yang membutuhkan latihan dan penguatan. Namun di sisi lain, terdapat hubungan yang signifikan antara kompetensi bahasa dan performansi bahasa, hal ini disebabkan tinggi rendahnya kompetensi kebahasaan terlihat pada keterampilan berbahasanya. Hubungan antara penguasaan nahwu yang dikuasai mahasiswa dengan kemampuan mahasiswa dalam menulis teks Arab tidak memiliki hubungan yang signifikan, maka kesimpulan yang diambil oleh peneliti adalah mahasiswa memahami nahwu secara teoritis dan bukan pemahaman praktis atau terapan sehingga pemahaman tersebut belum mampu menguatkan kemampuan menulisnya. Namun dalam hubungan antara penguasaan sintaksis, nahwu dan menulis teks Arab mahasiswa, terdapat hubungan yang cukup signifikan di antara

18. Fahrurrozi, op.cit. h. 146

19. Warsiman, Op. cit. , h. 11

${ }^{20}$. Nur Indah, Rohmani. Proses Pemerolehan Berbahasa Dari Kemampuan Hingga Kekurangmampuan, Artikel Online, https://www.researchgate.net/publication/279462683 diakses 04-06-2015 
ketiganya. Dengan bantuan struktur bahasa yang baik, maka kata atau kalimat yang dituliskan dalam bahasa Arab akan lebih mudah dipahami oleh pembaca.

\section{DAFTAR PUSTAKA}

Arikunto, Suharsimi, 1991. Prosedur Penelitian : Suatu Pendekatan Praktis. Jakarta : Rineka Cipta,.

Arifin, Zainal \& Tasai, S Amran. 2010. Cermat Berbahasa Indonesia. Jakarta : Akademika Presindo.

Arifin, Zainal \& Juniyah.2008 .Sintaksis.Bandung : Grasindo.

Arifin, Imam Khoirun, Jurnal online, Kemampuan Siswa dalam menggunakan kalimat efektif pada karangan narasi sekolah dasar SD 15 Air Saleh KabupatenBanyuasin,eprints.binadarma.ac.id/.../JURNAL\%20IMAM\%20KHO IRUL\%20ARIFI...) diakses 1-10-2015

Afriyanti,Sihombing, Skripsi. 2015.pengaruh pemahaman struktur dan ciri kebahasaan teks eksplanasi kompleks terhadap kemampuan menulis teks eksplanasi kompleks oleh siswa kelas xi sma negeri 20 medan tahun pembelajaran 2014/2015. Medan : Digital Library. Bulkisah. 2012. Jurnal online, Didaktika.Vol XII No. 2.

Al-Khuli, Muhammad Ali. 1989. Asâlib Tadris al-Lughah al-'arabiyyah, (Cetakan ketiga)

Badudu, 1989. Membaca Bahasa Baku Bahasa Indonesia. Bandung: Pustaka Prima

Chaer, Abdul, 2011. Tata Bahasa Praktis Bahasa Indonesia . Jakarta : Rineka Cipta Chaer, Abdul. Linguistik Umum. (Jakarta: Rineka Cipta)

Dayyab, Hifni dkk. 1986. Kaidah-kaidah bahasa Arab.Jakarta : Darul Ulum press.

Fahmi, Ahmad Akrom. 1999. Ilmu Nahwu dan Sharf 3, Praktis dan Aplikatif. Jakarta:Raja Grafindo Persada.

Fachrurrozi, Aziz \& Mahyuddin,Erta.2011. Teknik Pembelajaran Bahasa Arab. Bandung: Pustaka Cendekia Utama.

Fuad, ahmad. 2005. Metodologi Pengajaran Bahasa Arab. Malang : Misykat 
Hamdani, Agus. Artikel penelitian "Hubungan kompetensi sintaksis dengan performansi sintaksis". ejournal.kopertis4.or.id, diakses tgl 14 September 2015.

Alwi, Hasan. 2003. Tata Bahasa Baku Bahasa Indonesia.Jakarta : Balai Pustaka.

Hermawan, Acep.2011. Metodologi Pembelajaran Bahasa Arab. Bandung : Remaja Rosda Karya.

Kapoh, Ruty J.2010. Jurnal online. Beberapa faktor yang mempengaruhi dalam pemerolehan bahasa.Interlingua Vol.4 April .

Kridalaksana ,Harimurti. 2001. Kamus Linguistik. Jakarta: Gramedia Pustaka Utama.

Keraf. Gorys. 1995. Tata Bahasa Bahasa Indonesia. Ende Flores: Nusa Indah.

Keraf, Gorys. 1984 Tata Bahasa Indonesia. Flores: Nusa Indah

Lyons, Jhon.1996. Linguistics Semantics An Introduction. London: Cambridge University Perss.

Malik,AbdulY.Artikelonline http://owenalmulk.blogspot.co.id/2014/08/sintaksis.html, diakses 14-10-2015

Mariani, Scolastika,artikel online. http://scmarianiunnes.blogspot.co.id/2008/11/evaluasi-keterampilan-menulis.html, diakses tanggal 13-10-2015.

Matsna, Moh Hs \& Mahyuddin,Erta. 2012. Pengembangan Evaluasi dan Tes Bahasa Arab. Jakarta : Al-Kitabah.

Moh. Nasir. 1988. Metodologi Penelitian. Jakarta: Ghalia Indonesia.

Muchlisah,dkk.1992. Pendidikan Bahasa Indonesia3. Jakarta : Depdiknas.

Neli, No. 2 Juli 2012. Problematika Menulis Bahasa Arab, Jurnal Penelitian online.Jurnal At-Ta'lim Jilid 1. diakses tgl 7-09-2015).

Nurgiyantoro, burhan. 2001. Penilaian Dalam Pengajaran Bahasa Dan Sastra. Yogyakarta: BPFE Yogyakarta.

Parera, Jos Daniel.1988. Sintaksis Edisi Kedua. Jakarta : Gramedia

Purwadarminta, W.J.S. 1985. Kamus Umum Bahasa Indonesia. Jakarta: Balai Pustaka. 
Putrayasa, Ida Bagus.2008. Analisis Kalimat, Fungsi dan Peran, Bandung : Refika Aditama

Sabarti Akhadiah, dkk. 1987. Pembinaan Kemampuan Menulis Bahasa Indonesia. Jakarta: CV Manasco.

Safari. 1997. Pengujian dan Penilaian Bahasa dan Sastra Indonesia. Jakarta: Kartanegara.

Suparmanto.

Makalah online.http://suparmantomaman.blogspot.co.id/2014 0623 archive.html.

Ramlan, M. 2001. Ilmu Bahasa Indonesia Sintaksis. Yogyakarta : CV. Karyono.

Rohmani, Nur Indah. Proses Pemerolehan Berbahasa Dari Kemampuan Hingga Kekurangmampuan, Artikel Online, diakses 07-05-2015.

Samsuri. 1987. Analisis Bahasa. Jakarta: Erlangga.

Slamet. St. Y. 2008. Dasar-dasar keterampilan berbahasa Indonesia. Surakarta : UNS Press.

Sudjana. 1992. Metode Statistik. Bandung. Tarsito.

Supranto, 2004. Analisis Multivariat, Arti dan Interpretasi . Jakarta : Rineka Cipta

Suryabrata, Sumadi,1994. Metodologi Penelitian. Jakarta: Raja Grafindo Persada

Syafi'ie, I. 1988. Retorika dalam Menulis. Jakarta: Depdikbud.

Tarigan, Henry Guntur. 1984. Prinsip-prinsip Dasar Sintaksis. Bandung: Angkasa.

Tarigan, Henry Guntur. 1987. Menulis sebagai Suatu Keterampilan Berbahasa. Bandung: Tarsito.

Tarigan, Henry Guntur. 1988. Membaca sebagai Suatu Keterampilan Berbahasa. Bandung: Tarsito.

Warsiman, 2011,Keterkaitan Bahasa Bahasa dan Logika Dalam Berpikir Kritis. jurnal Prosodi, volume V Nomor 1 Januari 2011. Online, diakses 25-11-2015

Warsito, Tri , Tesis.2009 " Hubungan Antara Motivasi Belajar Dan Kemampuan Menyimak Dengan Keterampilan Menulis Siswa Kelas V Sekolah Dasar Sekecamatan Girimarto ,

Verhaar, J.W.M. 1996. Pengantar Linguistik. Yogyakarta: Gramedia Unyversity Perss. 